\title{
Angiotensinogen and Interleukin-18 as Markers of Chronic Kidney Damage in Children With a History of Hemolytic Uremic Syndrome
}

\author{
K. LIPIEC ${ }^{1}$, P. ADAMCZYK ${ }^{2}$, E. ŚWIĘTOCHOWSKA ${ }^{3}$, K. ZIORA ${ }^{2}$, M. SZCZEPAŃSKA ${ }^{2}$ \\ ${ }^{1}$ Department of Pediatric Nephrology with Dialysis Division for Children, Zabrze, Poland, \\ ${ }^{2}$ Department and Clinic of Pediatrics, School of Medicine with the Division of Dentistry \\ in Zabrze, Medical University of Silesia in Katowice, Zabrze, Poland, ${ }^{3}$ Chair and Department of \\ Medical and Molecular Biology, School of Medicine with the Division of Dentistry in Zabrze, \\ Medical University of Silesia in Katowice, Zabrze, Poland
}

Received March 6, 2016

Accepted August 26, 2016

On-line December 16, 2016

\begin{abstract}
Summary
Hemolytic uremic syndrome (HUS) is a type of thrombotic microangiopathy, in the course of which some patients may develop chronic kidney disease (CKD). It is clinically important to investigate the markers of a poor prognosis. The levels of angiotensinogen (AGT) and interleukin-18 (IL-18) in serum and urine were evaluated. Study was conducted in 29 children with a history of HUS. Serum and urine AGT concentration was significantly higher in children after HUS as compared to the control group. No differences depending on the type of HUS and gender were noted. The serum concentration of IL-18 in children after HUS was significantly lower, whereas in urine did not differ significantly between the sick and healthy children. A negative correlation between the concentration of AGT in serum and albuminuria in patients after HUS was detected. The results indicate that the concentration of AGT in serum and urine in children after HUS increases, which may indicate the activation of the intrarenal renin-angiotensin-aldosterone system. The statement, that AGT may be a good biomarker of CKD after acute kidney injury due to HUS requires prospective studies with follow-up from the acute phase of the disease on a larger group of patients. Reduced IL-18 serum concentration in children after HUS with no difference in its urine concentration may indicate a loss of the protective effects of this cytokine on renal function due to previously occurred HUS.
\end{abstract}

\section{Key words}

Hemolytic-uremic syndrome $\bullet$ Chronic kidney disease • Children • Angiotensinogen $\bullet$ IL-18

\section{Corresponding author}

M. Szczepańska, Department and Clinic of Pediatrics, SMDZ in Zabrze, SUM in Katowice, ul. 3 Maja 13/15, 41-800 Zabrze, Poland. E-mail: mszczepanska@szpital.zabrze.pl

\section{Introduction}

Hemolytic uremic syndrome (HUS) is the most common cause of acute kidney injury in previously healthy infants and young children. Together with thrombotic thrombocytopenic purpura (TTP) HUS belongs to a group of thrombotic microangiopathies (TMA). It is characterized by a triad of symptoms hemolytic anemia, thrombocytopenia and acute renal injury. Due to the different etiology and clinical course of HUS is divided into typical and atypical form (Picard et al. 2015). There are also many forms of HUS associated with coexisting disease or condition such as: drug induced, cancer-related, occurring after bone marrow and solid organs transplantation, in the course of autoimmunologic diseases, caused by HIV infection etc. (Adamczuk et al. 2009, Jander et al. 2013, Zurowska 2012).

Typical form of HUS, which constitutes $90 \%$ of cases of the disease, occurs most often in younger children (Adamczuk et al. 2009, Zurowska 2012, Franchini 2015). Verotoxin or Shiga-like toxin, produced by entero-hemorrhagic strains of Escherichia coli or Shigella dysenteriae is responsible for the damage of 
endothelial cells in this condition (Picard et al. 2015, Jander et al. 2013, Nester et al. 2015). Current mortality in typical form of HUS does not exceed $10 \%$. In the vast majority of patients the recovery of renal function with normal glomerular filtration rate is observed. In some patients the disease leads to chronic kidney disease (CKD) including end-stage renal failure (Lumbreras Fernandez et al. 2010).

Atypical hemolytic-uremic syndrome (aHUS) in $2 / 3$ of cases is not preceded by diarrhea, may be of family occurrence and is characterized by recurrent course (Adamczuk et al. 2009, Zurowska 2012). aHUS is an heterogeneous group of disorders related to defects in immune and coagulation systems (Jander et al. 2013). We know that in majority of patients aHUS relates to permanent abnormal activation of the complement system (the alternative pathway), caused by mutations of genes encoding proteins of the complement system $(\mathrm{C} 3$ protein, factor $\mathrm{H}$, factor $\mathrm{I}$, factor $\mathrm{B}$, membrane cofactor protein (MCP), thrombomodulin) and the presence of antibodies against factor $\mathrm{H}$. These mutations are both of inactivation (gene encoding factor $\mathrm{H}, \mathrm{MCP}$, thrombomodulin) or activation (C3 protein, factor B) (Wong et al. 2016, Nester et al. 2015). There are also mutations in other genes, e.g. newly discovered mutations of the gene encoding diacylglycerol kinase (DGKE) (Loirat et al. 2016), and some patients may have the causative mutations in more than one gene (Wong et al. 2016). aHUS is characterized by a poor prognosis, is burdened with significant mortality and $50 \%$ of the patients require renal replacement therapy (Adamczuk et al. 2009).

In recent years rapid progress both in understanding the pathophysiology and the treatment of aHUS has been done. By the year 2011, the basic tool for the treatment of aHUS was plasma therapy - prophylactic and therapeutic infusions of fresh frozen plasma or therapeutic plasma exchange (Picard et al. 2015, Nester 2015). Currently, the most effective treatment in aHUS is eculizumab therapy, which improved significantly the outcome (Picard et al. 2015, Franchini 2015, Loirat et al. 2016, Nester 2015).

Children with a history of HUS require continuous monitoring because they may reveal the features of reduced renal function even many years after the acute phase of the illness. An important concern is early identification of patients at risk of poor prognosis. Serum creatinine evaluation with the calculation of estimated glomerular filtration rate, albuminuria assessment (albumin/creatinine ratio $-\mathrm{ACR}$ ) or ultrasound of the kidneys are not sufficient to reach that aim. Hence there is a need to look for sensitive and specific markers that would identify the early stages of kidney damage. It seems that angiotensinogen (AGT) and interleukin-18 (IL-18) appear among such markers.

\section{The aim of the study}

We evaluated the concentration of AGT and IL-18 in serum and urine in children with a history of HUS as compared to the concentrations in healthy children. We raised hypothesis if these markers may be used as indicators of renal function deterioration. We have also tried to answer whether AGT and IL-18 could be early predictors of worsening of renal function.

\section{Material and Methods}

The study group (HUS) consisted of 29 patients ( 9 girls and 20 boys) aged 1 to 15 years with confirmed past history of HUS diagnosed based on standard criteria (hemolytic anemia, thrombocytopenia and acute renal injury), treated at the Department and Clinic of Pediatrics in Zabrze, Medical University of Silesia in Katowice. In this group $86 \%$ children required renal replacement therapy in the acute phase of the disease, $62 \%$ of them peritoneal dialysis, $14 \%$ - hemodialysis, $10 \%$ - both peritoneal dialysis and hemodialysis and $14 \%$ of children did not require dialysis. In 15 children atypical HUS (aHUS) was diagnosed (negative stool culture, not coexisting defined disease, or condition, ADAMTS13 activity greater than $10 \%$ ). All the children from the study group at the time of study were treated pharmacologically: diuretics (4 children), calcium channel blockers ( 21 children), angiotensin converting enzyme inhibitors (ACE-I) (14 children), supplementation of bicarbonate (4 children), supplementation of iron and folic acid ( 9 children). Weight, height, blood pressure and routine biochemical tests were performed on admission. Body mass index (BMI) was calculated using the formula BMI = body weight $[\mathrm{kg}] /$ height $^{2}\left[\mathrm{~m}^{2}\right]$. To compare the values of blood pressure between diverse groups of children, standard deviation scores (SDSs) for systolic and diastolic blood pressure were calculated.

The control group consisted of 21 healthy children (11 girls and 10 boys) aged 1 to 15 years hospitalized for nocturnal enuresis or presenting with surgical procedures of one-day surgery. All children participating in the study were in good clinical condition, 
without signs of acute infection. The study was approved by the Bioethics Committee of the Medical University of Silesia in Katowice (Resolution No. CDF/0022/KB1/ $111 / 13$ of 10.22.2013 year) and written consent from parents or legal guardians, and/or patients was obtained.

\section{Laboratory tests}

Blood samples $(3-5 \mathrm{ml})$ for laboratory tests were drawn in Eppendorf tubes in the morning (8.00-9.00) during examination related to periodic control in out-patients clinic. After centrifugation $1000 \mathrm{x}$ for $15 \mathrm{~min}$ at $4{ }^{\circ} \mathrm{C}$, the serum was stored at $-20{ }^{\circ} \mathrm{C}$ until assayed. Urine samples $(50-100 \mathrm{ml})$ were collected at the same time as the blood samples, and also kept at $-20{ }^{\circ} \mathrm{C}$ until evaluated. Determination of concentrations of IL-18 and AGT was performed in the Chair and Department of Medical and Molecular Biology, School of Medicine with the Division of Dentistry (SMDZ) in Zabrze, Medical University of Silesia (SUM) in Katowice.

The concentration of IL-18 in serum and urine was performed by ELISA using a set of e-Bioscence (USA) according to the manufacturer's protocol. Determination of concentrations of AGT was carried out using a kit from Diaclone (France) according to the manufacturer's protocol. In children with a history of HUS panel of routine laboratory tests were collected and estimated glomerular filtration rate (eGFR) was calculated by the Schwartz formula $\left[\mathrm{ml} / \mathrm{min} / 1.73 \mathrm{~m}^{2}\right]$. Albuminuria [mg/day] was evaluated using $24 \mathrm{~h}$ urine collection. The relationship between the two markers and anthropometric measurements, the value of eGFR and albuminuria (expressed as albumin / creatinine ratio and daily urinary albumin excretion) have been evaluated.

\section{Statistical analysis}

The database was prepared in an Excel spreadsheet from Microsoft. For statistical calculations licensed version 10.0 software Statistica (StatSoft Inc., USA) was used. In the statistical analysis the level of significance $\mathrm{p}=0.05$ was set. The arithmetic mean, median, minimum and maximum value, lower and upper quartile and standard deviation were chosen as the parameters of descriptive statistics. For all parameters the compatibility of their distributions with a normal distribution was checked using the Shapiro-Wilk test. Homogeneity of variations was tested by Levene test. For variables with normal distribution parametric tests were used with a separate estimate of the variance. MannWhitney nonparametric test was used for comparisons of variables with distribution diverged from the normal one. In the analysis of correlation Pearson's test or Spearman's rank correlation test was conducted - according to the distribution of the considered variables.

\section{Results}

Anthropometric measurements and the age of the children are presented in Table 1 . The mean age did not differ significantly between the study group and the control group. The mean age of children in the study group at HUS onset was $3.4 \pm 3.5$ years, while the mean time from the HUS onset with acute renal failure until the current examination was $4.9 \pm 3.9$ years. The mean weight, height and BMI in the study group did not differ significantly from the values in comparison group. The results of laboratory tests in the group of children after HUS are reported in Table 2. Increased ACR $(122.0 \pm 378.7 \mathrm{mg} / \mathrm{g})$ and $24 \mathrm{~h}$ albumin excretion was noted. The mean value of eGFR in the study group was $96.5 \pm 19.8 \mathrm{ml} / \mathrm{min} / 1.73 \mathrm{~m}^{2}$ and in the majority of children remained within the normal range. Concentrations of the examined markers (AGT, IL-18) in serum and urine are shown in Table 3. Children with HUS had significantly higher concentrations of AGT in serum and urine as compared to healthy children. The concentration of IL-18 was significantly lower in the serum of children in the study group compared to the control group, whereas there was no difference between IL-18 level in the urine between the study group and the control group. A negative correlation between serum AGT levels and ACR was documented (Table 4). The concentration of IL-18 in serum and urine did not correlate with anthropometric and biochemical parameters in children after HUS. To eliminate the influence of results obtained in children early after HUS acute phase, we have evaluated additionally the data from 24 children, who were sampled more than 6 months after HUS in which calculation was repeated (data not shown). We have obtained similar results as presented in Tables with a negative correlation between serum AGT level in blood with ACR. Negative correlation between MAP (mean arterial pressure) and eGFR was additionally demonstrated $(r=-0.4143, \mathrm{p}=0.044)$. 
Table 1. Clinical characteristics of children evaluated after hemolytic-uremic syndrome and from control group.

\begin{tabular}{|c|c|c|c|c|}
\hline & \multicolumn{3}{|c|}{ HUS group } & \multirow{2}{*}{$\frac{\text { Control group }}{\text { Total group }(n=21)}$} \\
\hline & Total group $(n=29)$ & Girls (n=9) & Boys $(n=20)$ & \\
\hline \multirow{2}{*}{ Age (years) } & $8.4 \pm 4.3$ & $10.0 \pm 4.3$ & $7.6 \pm 4.2$ & $8.4 \pm 4.1$ \\
\hline & $(0.9-16.7)$ & $(3.7-15.2)$ & $(0.9-16.7)$ & $(0.9-17.2)$ \\
\hline \multirow{2}{*}{ Height $(\mathrm{cm})$} & $128.7 \pm 25.5$ & $142.5 \pm 23.7$ & $122.5 \pm 24.3^{*}$ & $128.2 \pm 25.2$ \\
\hline & $(80-176)$ & $(106-168)$ & $(80-176)$ & $(76-172)$ \\
\hline \multirow{2}{*}{ Height SDS } & $0.45 \pm 0.93$ & $0.92 \pm 0.73$ & $0.35 \pm 1.30$ & $-0.06 \pm 1.10$ \\
\hline & $(-1.86-1.92)$ & $(-0.16-1.92)$ & $(-1.86-1.60)$ & $(-1.53-2.35)$ \\
\hline \multirow{2}{*}{ Body weight (kg) } & $30.3 \pm 17.1$ & $42.5 \pm 19.8$ & $24.7 \pm 12.7^{*}$ & $31.9 \pm 16.5$ \\
\hline & $(7.4-66.0)$ & $(17.3-66.0)$ & $(7.4-62.0)$ & $(9.7-63.0)$ \\
\hline \multirow{2}{*}{ Weight SDS } & $0.15 \pm 0.82$ & $0.85 \pm 0.68$ & $-0.17 \pm 0.68^{*}$ & $0.11 \pm 1.30$ \\
\hline & $(-1.63-2.04)$ & $(-0.36-2.04)$ & $(-1.63-1.30)$ & $(-1.87-2.12)$ \\
\hline \multirow{2}{*}{$B M I\left(k g / m^{2}\right)$} & $16.7 \pm 3.6$ & $19.6 \pm 4.7$ & $15.4 \pm 2.0^{*}$ & $15.40 \pm 2.08$ \\
\hline & $(10.0-28.6)$ & $(14.7-28.5)$ & $(10-20)$ & $(10-20)$ \\
\hline \multirow{2}{*}{$B M I S D S$} & $-0.20 \pm 1.00$ & $0.45 \pm 0.86$ & $-0.52 \pm 0.92 *$ & $0.32 \pm 1.02$ \\
\hline & $(-2.36-2.08)$ & $(-0.68-2.08)$ & $(-2.36-1.01)$ & $(-1.22-2.29)$ \\
\hline Age at HUS onset & $3.4 \pm 3.5$ & $5.0 \pm 4.7$ & $2.7 \pm 2.6$ & \\
\hline (years) & $(0.2-13.4)$ & $(0.9-13.4)$ & $(0.2-11.1)$ & \\
\hline Time after HUS & $4.9 \pm 4.0$ & $5.0 \pm 5.0$ & $4.9 \pm 3.5$ & \\
\hline (years) & $(0.04-13.90)$ & $(0.05-13.80)$ & $(0.04-11.00)$ & \\
\hline
\end{tabular}

Data are presented as mean \pm standard deviation (minimum-maximum), HUS - hemolytic-uremic syndrome, BMI - body mass index. $* p<0.05$ girls after HUS vs. boys after HUS.

\section{Discussion}

Renin-angiotensin-aldosterone system (RAS) as a system of hormone-enzyme properties controls the circulating blood volume and regulates the concentration of sodium and potassium ions in body fluids. The first of studied markers-AGT is a prohormone involved in RAS, produced in the liver and kidneys. In the renal tissue AGT is produced primarily by proximal tubular cells. Inside the lumen of the collecting ducts AGT can be converted to angiotensin I and II, by locally produced renin, prior to reaching the final urine (Sparks et al. 2014). To our knowledge, in the current study for the first time AGT levels in serum and urine in children with a history of HUS have been evaluated.

Intrarenal expression of AGT increases in experimental models of hypertension (Kobori et al. 2009, Kuroczycka-Saniutycz et al. 2013, Kobori et al. 2010). This increase was expressed by the activation of the AT1 receptor in the renal tubular cells via angiotensin II (Kobori et al. 2002, Kobori et al. 2003). AGT elevation detected exclusively in serum does not provide the direct evidence for its increased renal production. Numerous studies have suggested that AGT excretion in the urine may be a reliable marker of the activity of the intrarenal RAS (Kobori et al. 2003, Kobori et al. 2008, Kobori et al. 2009). There are many reports that proved the relationship between AGT excretion in the urine and severity of CKD (Kobori et al. 2008, Yamamoto et al. 2007, Mills et al. 2012). Higher concentration of AGT in urine has also been demonstrated in patients with diabetic nephropathy (Fishea 2015, Satirapoj et al. 2014, Kamiyama et al. 2012), in the course of the membranous glomerulonephritis (Urushihara and Kobori 2011), after kidney transplantation (Mas et al. 2011), and in IgA nephropathy (Urushihara et al. 2015). Kobori et al. (2009) in another study showed that AGT levels in urine positively correlated with systolic and diastolic blood pressure in patients with hypertension not treated with ACE inhibitors. The results of our study in children with a history of HUS clearly indicate that AGT levels in serum and urine obtained after acute phase of the disease are significantly higher. Therefore, it seems that AGT determination as a predictor of progression of CKD is potentially useful in children after acute kidney injury in the course of HUS, and can also help to choose 
Table 2. Biochemical parameters estimated glomerular filtration rate and blood pressure values in children after hemolytic-uremic syndrome.

\begin{tabular}{|c|c|c|c|c|c|}
\hline & $\begin{array}{l}\text { HUS total group } \\
\qquad(n=29)\end{array}$ & $\begin{array}{l}\text { HUS girls } \\
\quad(n=9)\end{array}$ & $\begin{array}{l}\text { HUS boys } \\
(n=20)\end{array}$ & aHUS & Typical HUS \\
\hline \multicolumn{6}{|l|}{ Serum } \\
\hline$G P T(U / l)$ & $\begin{array}{c}14.31 \pm 7.34 \\
(8.3-47.3)\end{array}$ & $\begin{array}{c}13.13 \pm 3.48 \\
(8.3-19.4)\end{array}$ & $\begin{array}{c}14.84 \pm 8.56 \\
(8.5-47.3)\end{array}$ & $\begin{array}{c}13.8 \pm 4.4 \\
(8.3-25.5)\end{array}$ & $\begin{array}{c}14.78 \pm 9.46 \\
(8.5-47.3)\end{array}$ \\
\hline Albumin $(g / l)$ & $\begin{array}{c}45.10 \pm 4.34 \\
(34.89-54.71)\end{array}$ & $\begin{array}{c}44.08 \pm 4.52 \\
(36.51-50.58)\end{array}$ & $\begin{array}{c}45.56 \pm 4.30 \\
(34.89-54.71)\end{array}$ & $\begin{array}{c}44.10 \pm 3.87 \\
(36.51-50.58)\end{array}$ & $\begin{array}{c}46.32 \pm 4.70 \\
(34.89-54.71)\end{array}$ \\
\hline Total proteins $(\mathrm{g} / \mathrm{l})$ & $\begin{array}{l}68.87 \pm 5.45 \\
(56.2-76.9)\end{array}$ & $\begin{array}{l}70.54 \pm 3.76 \\
(63.1-76.9)\end{array}$ & $\begin{array}{l}68.88 \pm 5.39 \\
(56.2-76.9)\end{array}$ & $\begin{array}{l}69.35 \pm 6.05 \\
(56.2-76.9)\end{array}$ & $\begin{array}{l}69.44 \pm 3.86 \\
(61.9-76.1)\end{array}$ \\
\hline $\begin{array}{l}\text { Total cholesterol } \\
(\mathrm{mmol} / \mathrm{l})\end{array}$ & $\begin{array}{c}4.18 \pm 0.88 \\
(2.84-5.95)\end{array}$ & $\begin{array}{c}4.02 \pm 0.80 \\
(2.99-5.58)\end{array}$ & $\begin{array}{c}4.25 \pm 0.92 \\
(2.84-5.95)\end{array}$ & $\begin{array}{c}3.98 \pm 0.87 \\
(2.84-5.58)\end{array}$ & $\begin{array}{c}4.37 \pm 0.88 \\
(3.19-5.95)\end{array}$ \\
\hline $\begin{array}{l}\text { HDL -cholesterol } \\
\text { (mmol/l) }\end{array}$ & $\begin{array}{c}1.74 \pm 0.33 \\
(1.13-2.24)\end{array}$ & $\begin{array}{c}1.49 \pm 0.25 \\
(1.15-1.73)\end{array}$ & $\begin{array}{c}1.84 \pm 0.32 \\
(1.13-2.24)\end{array}$ & $\begin{array}{c}1.60 \pm 0.25 \\
(1.13-1.88)\end{array}$ & $\begin{array}{c}1.88 \pm 0.36 \\
(1.15-2.24)\end{array}$ \\
\hline $\begin{array}{l}\text { LDL -cholesterol } \\
(\mathrm{mmol} / \mathrm{l})\end{array}$ & $\begin{array}{c}2.10 \pm 0.71 \\
(1.31-3.59)\end{array}$ & $\begin{array}{c}2.96 \pm 0.50 \\
(2.35-3.59)\end{array}$ & $\begin{array}{c}1.76 \pm 0.42 \\
(1.31-2.46)\end{array}$ & $\begin{array}{c}2.19 \pm 0.83 \\
(1.32-3.59)\end{array}$ & $\begin{array}{c}2.01 \pm 0.62 \\
(1.31-2.95)\end{array}$ \\
\hline $\begin{array}{l}\text { Triglycerides } \\
(\mathrm{mmol} / \mathrm{l})\end{array}$ & $\begin{array}{c}1.12 \pm 0.59 \\
(0.50-2.91)\end{array}$ & $\begin{array}{c}1.00 \pm 0.32 \\
(0.60-1.58)\end{array}$ & $\begin{array}{c}1.17 \pm 0.68 \\
(0.50-2.95)\end{array}$ & $\begin{array}{c}1.18 \pm 0.78 \\
(0.50-2.91)\end{array}$ & $\begin{array}{c}1.05 \pm 0.33 \\
(0.59-1.70)\end{array}$ \\
\hline Creatinine (umol/l) & $\begin{array}{c}50.27 \pm 11.95 \\
(34-82)\end{array}$ & $\begin{array}{c}53.44 \pm 12.02 \\
(34-73)\end{array}$ & $\begin{array}{c}48.85 \pm 11.95 \\
(34-82)\end{array}$ & $\begin{array}{c}53.1 \pm 14.2 \\
(34-82)\end{array}$ & $\begin{array}{c}47.67 \pm 9.14 \\
(34-64)\end{array}$ \\
\hline Uric acid (umol/l) & $\begin{array}{c}251.0 \pm 61.7 \\
(123-386)\end{array}$ & $\begin{array}{c}260.9 \pm 74.0 \\
(195-386)\end{array}$ & $\begin{array}{c}247.9 \pm 56.9 \\
(123-369)\end{array}$ & $\begin{array}{c}259.4 \pm 74.9 \\
(123-286)\end{array}$ & $\begin{array}{c}244.9 \pm 48.4 \\
(174-328)\end{array}$ \\
\hline Urea $(\mathrm{mmol} / \mathrm{l})$ & $\begin{array}{l}4.30 \pm 1.97 \\
(2.1-11.2)\end{array}$ & $\begin{array}{c}3.63 \pm 1.12 \\
(2.5-5.7)\end{array}$ & $\begin{array}{l}4.61 \pm 2.21 \\
(2.1-11.2)\end{array}$ & $\begin{array}{l}5.12 \pm 2.41 \\
(2.5-11.2)\end{array}$ & $\begin{array}{c}3.54 \pm 1.03 \# \\
(2.1-5.8)\end{array}$ \\
\hline \multicolumn{6}{|l|}{ Urine } \\
\hline $\begin{array}{l}\text { Daily albumin } \\
\text { excretion (mg/day) }\end{array}$ & $\begin{array}{l}52.69 \pm 108.37 \\
(1.65-477.75)\end{array}$ & $\begin{array}{l}26.99 \pm 25.99 \\
(6.62-76.99)\end{array}$ & $\begin{array}{l}62.97 \pm 127.04 \\
(1.65-477.70)\end{array}$ & $\begin{array}{c}81.45 \pm 161.60 \\
(10.16-477.70)\end{array}$ & $\begin{array}{c}35.00 \pm 58.72 \\
(1.65-195.12)\end{array}$ \\
\hline Albuminuria $(\mathrm{mg} / \mathrm{l})$ & $\begin{array}{l}56.46 \pm 157.26 \\
(4.18-735.00)\end{array}$ & $\begin{array}{l}17.40 \pm 19.35 \\
(4.41-54.99)\end{array}$ & $\begin{array}{l}71.11 \pm 183.46 \\
(4.18-735.00)\end{array}$ & $\begin{array}{c}106.47 \pm 254.46 \\
(5.40-735.00)\end{array}$ & $\begin{array}{c}27.89 \pm 51.63 \\
(4.18-186.55)\end{array}$ \\
\hline$A C R(\mathrm{mg} / \mathrm{g})$ & $\begin{array}{l}122.0 \pm 378.7 \\
(7.1-1800.3)\end{array}$ & $\begin{array}{c}40.4 \pm 33.8 \\
(10.0-100.9)\end{array}$ & $\begin{array}{l}152.6 \pm 443.5 \\
(7.1-1800.3)\end{array}$ & $\begin{array}{l}257.6 \pm 624.1 \\
(13.5-1800.3)\end{array}$ & $\begin{array}{c}44.6 \pm 64.8 \\
(7.1-208.6)\end{array}$ \\
\hline$e G F R\left(\mathrm{ml} / \mathrm{min} / 1.73 \mathrm{~m}^{2}\right)$ & $\begin{array}{c}96.53 \pm 19.84 \\
(38.25-127.78)\end{array}$ & $\begin{array}{c}99.29 \pm 14.38 \\
(80.27-119.19)\end{array}$ & $\begin{array}{c}95.28 \pm 22.08 \\
(38.29-127.78)\end{array}$ & $\begin{array}{c}90.43 \pm 22.44 \\
(38.29-119.19)\end{array}$ & $\begin{array}{c}102.22 \pm 15.75 \\
(73.02-127.78)\end{array}$ \\
\hline \multicolumn{6}{|l|}{ Blood pressure } \\
\hline$S B P S D S$ & $\begin{array}{c}0.57 \pm 1.22 \\
(-1.29-3.49)\end{array}$ & $\begin{array}{c}1.07 \pm 1.09 \\
(-0.52-2.97)\end{array}$ & $\begin{array}{c}0.36 \pm 1.24 \\
(-1.29-3.49)\end{array}$ & $\begin{array}{c}0.83 \pm 1.36 \\
(-1.29-3.49)\end{array}$ & $\begin{array}{c}0.34 \pm 1.06 \\
(-0.98-2.97)\end{array}$ \\
\hline$D B P S D S$ & $\begin{array}{c}0.41 \pm 1.07 \\
(-1.18-3.05)\end{array}$ & $\begin{array}{c}0.44 \pm 1.01 \\
(-1.13-2.15)\end{array}$ & $\begin{array}{c}0.40 \pm 1.13 \\
(-1.18-3.05)\end{array}$ & $\begin{array}{c}0.66 \pm 1.19 \\
(-0.92-3.05)\end{array}$ & $\begin{array}{c}0.18 \pm 0.92 \\
(-1.18-1.80)\end{array}$ \\
\hline$M A P(m m ~ H g)$ & $\begin{array}{c}76.9 \pm 8.9 \\
(61.7-99.3)\end{array}$ & $\begin{array}{c}82.4 \pm 10.2 \\
(69.7-99.3)\end{array}$ & $\begin{array}{c}74.5 \pm 7.4^{*} \\
(61.7-87.7)\end{array}$ & $\begin{array}{c}78.83 \pm 8.33 \\
(64.33-91.67)\end{array}$ & $\begin{array}{c}75.16 \pm 9.41 \\
(61.67-99.33)\end{array}$ \\
\hline
\end{tabular}

Data are presented as mean \pm standard deviation (minimum-maximum), HUS - hemolytic-uremic syndrome, eGFR - estimated glomerular filtration rate, ACR - albumin/creatinine ratio, SBP - systolic blood pressure, DBP - diastolic blood pressure, MAP - mean arterial pressure. ${ }^{*} p<0.05$ girls after HUS vs. boys after HUS, $\# p<0.05$ atypical HUS vs. typical HUS. 
Table 3. Mean concentration of examined markers in children after hemolytic-uremic syndrome and in control group.

\begin{tabular}{lcccccc}
\hline & $\begin{array}{c}\text { Children after HUS } \\
(\mathbf{n}=\mathbf{2 9})\end{array}$ & $\begin{array}{c}\text { Girls after HUS } \\
(\mathbf{n = 9})\end{array}$ & $\begin{array}{c}\text { Boys after HUS } \\
(\mathbf{n = 2 0})\end{array}$ & $\begin{array}{c}\text { Atypical HUS } \\
(\mathbf{n = 1 5})\end{array}$ & $\begin{array}{c}\text { Typical HUS } \\
(\mathbf{n = 1 4})\end{array}$ & $\begin{array}{c}\text { Control group } \\
(\mathbf{n}=\mathbf{2 1})\end{array}$ \\
\hline Serum & & & & & \\
& & & & & & \\
$I L-18$ & $50.55 \pm 6.82$ & $50.18 \pm 6.29$ & $50.71 \pm 7.20$ & $50.99 \pm 6.28$ & $50.13 \pm 7.49$ & $75.25 \pm 9.10^{*}$ \\
$(\mathrm{ng} / \mathrm{ml})$ & $(36.88-60.12)$ & $(40.27-57.91)$ & $(36.88-60.12)$ & $(41.28-59.61)$ & $(36.88-60.12)$ & $(60.57-98.72)$ \\
$A G T$ & $3.84 \pm 0.71$ & $3.64 \pm 0.84$ & $3.92 \pm 0.64$ & $3.70 \pm 0.79$ & $3.96 \pm 0.62$ & $2.42 \pm 0.35^{*}$ \\
$(n g / m l)$ & $(2.18-5.23)$ & $(2.18-5.23)$ & $(2.18-4.81)$ & $(2.18-4.81)$ & $(2.76-5.23)$ & $(1.87-3.11)$ \\
Urine & & & & & & \\
$I L-18$ & & & & & & \\
$(n g / m l)$ & $(1.72-19.84)$ & $(10.46-17.90)$ & $(1.72-19.84)$ & $(12.41-19.80)$ & $(1.72-17.92)$ & $(9.87-23.13)$ \\
$A G T$ & $3.59 \pm 0.63$ & $3.73 \pm 0.71$ & $3.52 \pm 0.60$ & $3.67 \pm 0.70$ & $3.51 \pm 0.58$ & $2.31 \pm 0.54 *$ \\
$(n g / m l)$ & $(2.11-4.77)$ & $(2.67-4.77)$ & $(2.11-4.71)$ & $(2.11-4.77)$ & $(2.61-4.71)$ & $(1.78-3.71)$ \\
\hline
\end{tabular}

Data are presented as mean \pm standard deviation (minimum-maximum), HUS - hemolytic-uremic syndrome, IL-18 - interleukin-18, AGT - angiotensinogen. ${ }^{*} p<0.05$ children after HUS vs. control group.

the optimal antihypertensive therapy. In our study, a significantly higher concentration of AGT in serum and urine was also found in children treated with ACE-I. Kobori et al. (2008) reported in another study that AGT excretion in the urine increases in adult patients with chronic kidney disease and additionally positively correlates with albuminuria and negatively with the value of eGFR. In our study there was no correlation between above mentioned parameters. However, children, presented only a slight degree of kidney function deterioration and most of them were treated with ACE-I. Yamamoto et al. (2007) have shown that the level of AGT in urine was significantly higher in patients with a low eGFR and proteinuria. Mills et al. (2012) demonstrated in adult patients with CKD the negative correlation between AGT levels in the urine and the value of the eGFR. In addition, they demonstrated that the level of AGT in the urine is independent of the value of albuminuria. AGT presence in urine may also be conditioned by leakage of protein through the slit membrane, when glomerular proteinuria is present (Mills et al. 2012). Thus, the study mentioned above indicates the role of AGT excreted in the urine as a possible marker for the detection of early stages of renal impairment. Our study in children with a history of HUS also confirms this hypothesis, but certainly there is a need for more clinical trials, especially with longitudinal design, provided in larger groups of patients, including pediatric population. Small number of examined children is the limitation of the study.

IL-18 was first described in 1989 as a "factor inducing IFN gamma". In 1995 it was named interleukin-18. This cytokine belongs to the family of IL-1 (Okamura et al. 1995) and is synthesized as an inactive precursor, then converted to the active form by the caspase-1 (Dinarello et al. 2013). In addition, the active form of IL-18 is also released during cell apoptosis (Bossaller et al. 2012). The receptor for IL-18 is situated on T cells, dendritic cells, mast cells, basophils, macrophages, neutrophils, cells, "natural killer" (NK) cells, endothelial cells and smooth muscle cells (Boraschi and Dinarello 2006, Dinarello 2007). It has been shown that IL-18 is involved in the pathogenesis of many diseases - including its confirmed activity in inflammatory bowel diseases (Pizarro et al. 1999, Siegmund 2010, Monteleone et al. 1999, Banerjee and Bond 2008), obesity (Netea et al. 2006, Zorrilla et al. 2007), and heart diseases (Platis et al. 2008, Woldbaek et al. 2005, Pomerantz et al. 2001, Mallat et al. 2004, Raeburn et al. 2002). There are also reports about the protective role of elevated levels of IL-18 in certain disease conditions (Dinarello et al. 2013, Doyle et al. 2012, Campbell et al. 2014). 
Table 4. Correlation between the studied markers of chronic kidney disease and the results of anthropometric measurements and biochemical parameters.

\begin{tabular}{|c|c|c|c|c|}
\hline & \multicolumn{4}{|c|}{ Examined children with HUS n=29 (HUS) } \\
\hline & IL-18 serum & IL-18 urine & AGT serum & AGT urine \\
\hline \multirow{2}{*}{ Body weight (kg) } & $\mathrm{r}=-0.067$ & $\mathrm{r}=0.082$ & $\mathrm{r}=-0.010$ & $\mathrm{r}=-0.225$ \\
\hline & $\mathrm{p}=0.729$ & $\mathrm{p}=0.671$ & $\mathrm{p}=0.957$ & $\mathrm{p}=0.239$ \\
\hline \multirow{2}{*}{ Height (cm) } & $\mathrm{r}=-0.060$ & $\mathrm{r}=0.100$ & $\mathrm{r}=0.064$ & $\mathrm{r}=-0.236$ \\
\hline & $\mathrm{p}=0.754$ & $\mathrm{p}=0.605$ & $\mathrm{p}=0.742$ & $\mathrm{p}=0.216$ \\
\hline \multirow{2}{*}{ Age (l) } & $\mathrm{r}=0.009$ & $\mathrm{r}=0.076$ & $\mathrm{r}=0.145$ & $\mathrm{r}=-0.306$ \\
\hline & $\mathrm{p}=0.962$ & $\mathrm{p}=0.692$ & $\mathrm{p}=0.453$ & $\mathrm{p}=0.106$ \\
\hline \multirow{2}{*}{ Age at HUS onset (l) } & $\mathrm{r}=-0.026$ & $\mathrm{r}=0.023$ & $\mathrm{r}=-0.161$ & $\mathrm{r}=0.008$ \\
\hline & $\mathrm{p}=0.172$ & $\mathrm{p}=0.905$ & $\mathrm{p}=0.403$ & $\mathrm{p}=0.966$ \\
\hline \multirow{2}{*}{ Time from HUS onset (l) } & $\mathrm{r}=0.240$ & $\mathrm{r}=0.063$ & $\mathrm{r}=0.300$ & $\mathrm{r}=-0.340$ \\
\hline & $\mathrm{p}=0.209$ & $\mathrm{p}=0.745$ & $\mathrm{p}=0.113$ & $\mathrm{p}=0.071$ \\
\hline \multirow{2}{*}{ MAP (mm Hg) } & $\mathrm{r}=-0.130$ & $\mathrm{r}=0.124$ & $\mathrm{r}=0.312$ & $\mathrm{r}=0.125$ \\
\hline & $\mathrm{p}=0.500$ & $\mathrm{p}=0.519$ & $\mathrm{p}=0.099$ & $\mathrm{p}=0.517$ \\
\hline \multirow{2}{*}{$G P T(U / l)$} & $\mathrm{r}=-0.311$ & $\mathrm{r}=-0.106$ & $\mathrm{r}=-0.140$ & $\mathrm{r}=0.243$ \\
\hline & $\mathrm{p}=0.100$ & $\mathrm{p}=0.583$ & $\mathrm{p}=0.468$ & $\mathrm{p}=0.204$ \\
\hline \multirow{2}{*}{ Serum albumin $(g / l)$} & $\mathrm{r}=0.106$ & $\mathrm{r}=0.127$ & $\mathrm{r}=-0.084$ & $\mathrm{r}=-0.074$ \\
\hline & $\mathrm{p}=0.605$ & $\mathrm{p}=0.533$ & $\mathrm{p}=0.680$ & $\mathrm{p}=0.716$ \\
\hline \multirow{2}{*}{ Total proteins $(g / l)$} & $\mathrm{r}=0.124$ & $\mathrm{r}=-0.099$ & $\mathrm{r}=0.086$ & $\mathrm{r}=0.217$ \\
\hline & $\mathrm{p}=0.519$ & $\mathrm{p}=0.607$ & $\mathrm{p}=0.657$ & $\mathrm{p}=0.258$ \\
\hline \multirow{2}{*}{ Total cholesterol (mmol/l) } & $\mathrm{r}=-0.319$ & $\mathrm{r}=-0.019$ & $\mathrm{r}=-0.173$ & $\mathrm{r}=0.335$ \\
\hline & $\mathrm{p}=0.091$ & $\mathrm{p}=0.919$ & $\mathrm{p}=0.369$ & $\mathrm{p}=0.075$ \\
\hline \multirow{2}{*}{ HDL cholesterol (mmol/l) } & $\mathrm{r}=-0.012$ & $\mathrm{r}=-0.294$ & $\mathrm{r}=0.135$ & $\mathrm{r}=0.100$ \\
\hline & $\mathrm{p}=0.967$ & $\mathrm{p}=0.307$ & $\mathrm{p}=0.645$ & $\mathrm{p}=0.732$ \\
\hline \multirow{2}{*}{ LDL cholesterol $(\mathrm{mmol} / \mathrm{l})$} & $\mathrm{r}=-0.081$ & $\mathrm{r}=0.072$ & $\mathrm{r}=-0.500$ & $\mathrm{r}=0.402$ \\
\hline & $\mathrm{p}=0.783$ & $\mathrm{p}=0.804$ & $\mathrm{p}=0.066$ & $\mathrm{p}=0.153$ \\
\hline \multirow{2}{*}{ Triglycerides (mmol/l) } & $\mathrm{r}=0.100$ & $\mathrm{r}=-0.059$ & $\mathrm{r}=0.238$ & $\mathrm{r}=0.288$ \\
\hline & $\mathrm{p}=0.611$ & $\mathrm{p}=0.764$ & $\mathrm{p}=0.221$ & $\mathrm{p}=0.137$ \\
\hline \multirow{2}{*}{ Creatinine (umol/l) } & $\mathrm{r}=-0.158$ & $\mathrm{r}=0.147$ & $\mathrm{r}=0.276$ & $\mathrm{r}=-0.080$ \\
\hline & $\mathrm{p}=0.412$ & $\mathrm{p}=0.446$ & $\mathrm{p}=0.146$ & $\mathrm{p}=0.669$ \\
\hline \multirow{2}{*}{ Uric acid (umol/l) } & $\mathrm{r}=-0.0003$ & $\mathrm{r}=0.092$ & $\mathrm{r}=0.270$ & $\mathrm{r}=0.206$ \\
\hline & $\mathrm{p}=0.999$ & $\mathrm{p}=0.632$ & $\mathrm{p}=0.157$ & $\mathrm{p}=0.283$ \\
\hline \multirow{2}{*}{ Urea (mmol/l) } & $\mathrm{r}=-0.039$ & $\mathrm{r}=0.070$ & $\mathrm{r}=0.150$ & $\mathrm{r}=0.046$ \\
\hline & $\mathrm{p}=0.838$ & $\mathrm{p}=0.716$ & $\mathrm{p}=0.435$ & $\mathrm{p}=0.812$ \\
\hline \multirow{2}{*}{$A C R(m g / g)$} & $\mathrm{r}=-0.262$ & $\mathrm{r}=0.021$ & $\mathrm{r}=-0.456^{*}$ & $\mathrm{r}=0.162$ \\
\hline & $\mathrm{p}=0.238$ & $\mathrm{p}=0.924$ & $\mathrm{p}=\mathbf{0 . 0 3 3}$ & $\mathrm{p}=0.471$ \\
\hline \multirow{2}{*}{$e G F R\left(\mathrm{ml} / \mathrm{min} / 1.73 \mathrm{~m}^{2}\right)$} & $\mathrm{r}=0.203$ & $\mathrm{r}=-0.059$ & $\mathrm{r}=-0.219$ & $\mathrm{r}=-0.109$ \\
\hline & $\mathrm{p}=0.289$ & $\mathrm{p}=0.760$ & $\mathrm{p}=0.252$ & $\mathrm{p}=0.570$ \\
\hline
\end{tabular}

* Correlation coefficients are significant $p<0.05, \mathrm{ACR}$ - albumin/creatinine ratio.

The usefulness of IL-18 evaluation in serum and urine as an additional marker of the early stages of renal damage was explored in our study as well. It was shown that the serum IL-18 in children who have previously had HUS and acute renal failure is significantly lower than in controls. However, we found no difference in the concentrations of IL-18 in the urine in patients with a history of HUS as compared to the control group of healthy children.

It has been known for a long time that CKD 
regardless of its cause is accompanied by inflammation, and the intensity of inflammation correlates negatively with renal function. The role of inflammation mediators, including pro-inflammatory cytokines (with IL-18 among them) in the progression of CKD is constantly discussed. In the literature there are only scarce reports on the role of IL-18 in the development of CKD (45). The most important and the earliest discovered function of IL-18 is its action as a part of a Th1-type immune response or the ability to induce IFN-gamma by Th1 and NK cells. IL-18 is also involved in the immune response of Th2 type inducing the production of IL-4 and IL-13 in Th2 cells, NK cells, as well as in mast cells and basophils (Nakanishi et al. 2001, Gołąb et al. 2012). IL-18 may also stimulate the population of Th17 cells to produce IL-17, thus promoting the autoimmune response (Coccia et al. 2012, Lalor et al. 2011). Liang et al. (2007) did not exclude that IL-18 might play a role in the process of interstitial fibrosis and tubular atrophy (renal tubulointerstitial fibrosis - TIF) through the activation of tubular epithelial cells as the result of their injury (Liang et al. 2007). The role of IL-18 in the pathogenesis of renal disease is not fully understood, but it appears that it is more the marker of acute injury than the marker of CKD. Liu et al. (2013) argue that increased concentrations of IL-18 in the urine could be a useful biomarker of acute kidney injury. On the other hand, in another report the authors are proving that IL-18 has a poor ability to predict acute renal failure and should not be used as a marker for predicting acute renal injury (Nisula et al. 2015).

In some pathologies IL-18 may act as a protective factor (Dinarello et al. 2013). In our study, IL-18 serum levels in children after HUS were significantly lower as compared to healthy children. This may also reflect the loss of the protective role of IL-18 after acute kidney injury in the course of HUS. However, the limitation of our study is that based on presented data no HUS specific trend in IL-18 and AGT development can be suggested.

\section{Conclusions}

The results indicate that the concentration of angiotensinogen in serum and urine in children with a history of hemolytic-uremic syndrome increases, which may indicate the activation of the intrarenal RAS. The statement, that angiotensinogen may be a good biomarker of chronic kidney damage after acute kidney injury due to HUS requires further studies with prospective follow-up from the acute phase of the disease on a larger group of patients. Reduced IL-18 serum concentration in children after HUS with no difference in its urine concentration may indicate a loss of the protective effects of this cytokine on renal function due to previously occurred illness.

\section{Conflict of Interest}

There is no conflict of interest.

\section{Acknowledgements}

This work was financially supported by Grant KNW-1$150 / \mathrm{k} / 310$ from the Medical University of Silesia in Katowice, Poland.

\section{References}

ADAMCZUK D, BIEROZA I, ROSZKOWSKA-BLAIM M: Hemolytic uremic syndrome (in Polish). Nowa Pediatria 2: 63-67, 2009.

BANERJEE S, BOND JS: Prointerleukin-18 is activated by meprin beta in vitro and in vivo in intestinal inflammation. J Biol Chem 283: 31371-31377, 2008.

BORASCHI D, DINARELLO CA: IL-18 in autoimmunity: review. Eur Cytokin Netw 17: 224-252, 2006.

BOSSALLER L, CHIANG PI, SCHMIDT-LAUBER C, GANESAN S, KAISER WJ, RATHINAM VA, MOCARSKI ES, SUBRAMANIAN D, GREEN DR, SILVERMAN N, FITZGERALD KA, MARSHAK-ROTHSTEIN A, LATZ E: Cutting edge: FAS (CD95) mediates noncanonical IL-1 $\beta$ and IL-18 maturation via caspase- 8 in an RIP3-independent manner. Immunol 189: 5508-5512, 2012.

CAMPBELL M, DOYLE S, HUMPHRIES P: IL-18: a new player in immunotherapy for age-related macular degeneration? Expert Rev Clin Immunol 10: 1273-1275, 2014.

COCCIA M, HARRISON OJ, SCHIERING C, ASQUITH MJ, BECHER B, POWRIE F, MALOY KJ: IL-1 $\beta$ mediates chronic intestinal inflammation by promoting the accumulation of IL-17A secreting innate lymphoid cells and CD4(+) Th17 cells. J Exp Med 209: 1595-1609, 2012. 
DINARELLO CA: Interleukin-18 and the pathogenesis of inflammatory diseases. Semin Nephrol 27: 98-114, 2007.

DINARELLO CA, NOVICK D, KIM S, KAPLANSKI G: Interleukin-18 and IL-18 binding protein. Front Immunol 4: $289,2013$.

DOYLE SL, CAMPBELL M, OZAKI, SALOMON RG, MORI A, KENNA PF, FARRAR GJ, KIANG AS, HUMPHRIES MM, LAVELLE EC, O'NEILL LA, HOLLYFIELD JG, HUMPHRIES P: NLRP3 has a protective role in age-related macular degeneration through the induction of IL-18 by drusen components. Nat Med 18: 791-810, 2012.

FISEHA T: Urinary biomarkers for early diabetic nephropathy in type 2 diabetic patients. Biomark Res 3: 16, 2015.

FRANCHINI M: Atypical hemolytic uremic syndrome: from diagnosis to treatment. Clin Chem Lab Med 53: 1679$1688,2015$.

GOŁĄB J, JAKÓBISIAK M, FIRCZUK M: Cytokines (in Polish). In: Immunologia. GOŁĄB J, JAKÓBISIAK M, LASEK W, STOKŁOSA T (eds), Wydawnictwo naukowe PWN, Warszawa, 2012, pp 157-197.

JANDER A, KRAKOWSKA A, TKACZYK M: Atypical hemolytic uremic syndrome - case description (in Polish). MONZ 19: 75-77, 2013.

KAMIYAMA M, ZSOMBOK A, KOBORI H: Urinary angiotensinogen as a novel early biomarker of intrarenal reninangiotensin system activation in experimental type 1 diabetes. $J$ Pharmacol Sci 119: 314-323, 2012.

KOBORI H, HARRISON-BERNARD LM, NAVAR LG: Urinary excretion of angiotensinogen reflects intrarenal angiotensinogen production. Kidney Int 61: 579-585, 2002.

KOBORI H, NISHIYAMA A, HARRISON-BERNARD LM, NAVAR LG: Urinary angiotensinogen as an indicator of intrarenal angiotensin status in hypertension. Hypertension 41: 42-49, 2003.

KOBORI H, OHASHI N, KATSURADA A, MIYATA K, SATOU R, SAITO T, YAMAMOTO T: Urinary angiotensinogen as a potential biomarker of severity of chronic kidney diseases. J Am Soc Hypertens 2 : 349-354, 2008.

KOBORI H, ALPER AB JR, SHENAVA R, KATSURADA A, SAITO T, OHASHI N, URUSHIHARA M, MIYATA K, SATOU R, HAMM LL, NAVAR LG: Urinary angiotensinogen as a novel biomarker of the intrarenal reninangiotensin system status in hypertensive patients. Hypertension 53: 344-350, 2009.

KOBORI H, URUSHIHARA M, XU JH, BERENSON GS, NAVAR LG: Urinary angiotensinogen is correlated with blood pressure in men (Bogalusa Heart Study). J Hypertens 28: 1422-1428, 2010.

KUROCZYCKA-SANIUTYCZ E, WASILEWSKA A, SULIK A, MILEWSKI R: Urinary angiotensinogen as a marker of intrarenal angiotensin II activity in adolescents with primary hypertension. Pediatr Nephrol 28: 1113-1119, 2013.

LALOR SJ, DUNGAN LS, SUTTON CE, BASDEO SA, FLETCHER JM, MILLS KH: Caspase-1-processed cytokines IL-1beta and IL-18 promote IL-17 production by gammadelta and CD4 T cells that mediate autoimmunity. J Immunol 186: 5738-5748, 2011.

LIANG D, LIU HF, YAO CW, LIU HY, HUANG-FU CM, CHEN XW, DU SH, CHEN XW: Effects of interleukin 18 on injury and activation of human proximal tubular epithelial cells. Nephrology 12: 53-61, 2007.

LIU Y, GUO W, ZHANG J, XU C, YU S, MAO Z, WU J, YE C, MEI C, DAI B: Urinary interleukin 18 for detection of acute kidney injury: a meta-analysis. Am J Kidney Dis 62: 1058-1067, 2013.

LOIRAT C, FAKHOURI F, ARICETA G, BESBAS N, BITZAN M, BJERRE A, COPPO R, EMMA F, JOHNSON S, KARPMAN D, LANDAU D, LANGMAN CB, LAPEYRAQUE AL, LICHT C, NESTER C, PECORARO C, RIEDL M, VAN DE KAR NC, VAN DE WALLE J, VIVARELLI M, FRÉMEAUX-BACCHI V; FOR HUS INTERNATIONAL: An international consensus approach to the management of atypical hemolytic uremic syndrome in children. Pediatric Nephrol 31: 15-39, 2016.

LUMBRERAS FERNANDEZ J, CRUZ ROJO J, INIGI MARTIN G, MULEY ALONSO R, VARA MARTÍN J: Hemolytic uremic syndrome: long term renal injury. An Pediatr (Barc) 72: 309-316, 2010.

MALLAT Z, HEYMES C, CORBAZ A, LOGEART D, ALOUANI S, COHEN-SOLAL A, SEIDLER T, HASENFUSS G, CHVATCHKO Y, SHAH AM, TEDGUI A: Evidence for altered interleukin 18 (IL)-18 pathway in human heart failure. FASEB $J$ 18: 1752-1754, 2004.

MAS VR, MUELLER TF, ARCHER KJ, MALUF DG: Identifying biomarkers as diagnostic tools in kidney transplantation. Expert Rev Mol Diagn 11: 183-196, 2011. 
MILLS KT, KOBORI H, HAMM LL, ALPER AB, KHAN IE, RAHMAN M, NAVAR LG, LIU Y, BROWNE GM, BATUMAN V, HE J, CHEN J: Increased urinary excretion of angiotensinogen is associated with risk of chronic kidney disease. Nephrol Dial Transplant 27: 3176-3181, 2012.

MONTELEONE G, TRAPASSO F, PARRELLO T, BIANCONE L, STELLA A, IULIANO R, LUZZA F, FUSCO A, PALLONE F: Bioactive IL-18 expression is up-regulated in Crohn's disease. J Immunol 163: 143-147, 1999.

NAKANISHI K, YOSHIMOTO T, TSUTSUI H, OKAMURA H: Interleukin-18 is a unique cytokine that stimulates both Th1 and Th2 responses depending on its cytokine milieu. Cytokine Growth Factor Rev 12: 53-72, 2001.

NESTER CM: Managing atypical hemolytic uremic syndrome: chapter 2. Kidney Int 87: 882-884, 2015.

NESTER CM, BARBOUR T, DE CORDOBA SR, DRAGON-DUREY MA, FREMEAUX-BACCHI V, GOODSHIP TH, KAVANAGH D, NORIS M, PICKERING M, SANCHEZ-CORRAL P, SKERKA C, ZIPFEL P, SMITH RJ: Atypical aHUS: state of the art. Mol Immunol 67: 31-42, 2015.

NETEA MG, JOOSTEN LA, LEWIS E, JENSEN DR, VOSHOL PJ, KULLBERG BJ, TACK CJ, VAN KRIEKEN H, KIM SH, STALENHOEF AF, VAN DE LOO FA, VERSCHUEREN I, PULAWA L, AKIRA S, ECKEL RH, DINARELLO CA, VAN DEN BERG W, VAN DER MEER JW: Deficiency of interleukin-18 in mice leads to hyperphagia, obesity and insulin resistance. Nat Med 12: 650-656, 2006.

NISULA S, YANG R, POUKKANEN M, VAARA ST, KAUKONEN KM, TALLGREN M, HAAPIO M, TENHUNEN J, KORHONEN AM, PETTILÄ V; FINNAKI STUDY GROUP: Predictive value of urine interleukin-18 in the evolution and outcome of acute kidney injury in critically ill adult patients. Br J Anaesth 114: 460-468, 2015.

OKAMURA H, NAGATA K, KOMATSU T, TANIMOTO T, NUKATA Y, TANABE F, AKITA K, TORIGOE K, OKURA T, FUKUDA S: A novel costimulatory factor for gamma interferon induction found in the livers of mice causes endotoxic shock. Infect Immun 63: 3966-3972, 1995.

PICARD C, BURTEY S, BORNET C, CURTI C, MONTANA M, VANELLE P: Pathophysiology and treatment of typical and atypical hemolytic uremic syndrome. Pathol Biol 63: 136-143, 2015.

PIZARRO TT, MICHIE MH, BENTZ M, WORARATANADHARM J, SMITH MF JR, FOLEY E, MOSKALUK CA, BICKSTON SJ, COMINELLI F: IL-18, a novel immunoregulatory cytokine, is up-regulated in Crohn's disease: expression and localization in intestinal mucosal cells. J Immunol 162: 6829-6835, 1999.

PLATIS A, YU Q, MOORE D, KHOJEINI E, TSAU P, LARSON D: The effect of daily administration of IL-18 on cardiac structure and function. Perfusion 23: 237-242, 2008.

POMERANTZ BJ, REZNIKOV LL, HARKEN AH, DINARELLO CA: Inhibition of caspase 1 reduces human myocardial ischemic dysfunction via inhibition of IL-18 and IL-1beta. Proc Natl Acad Sci USA 98: 2871-2876, 2001.

RAEBURN CD, DINARELLO CA, ZIMMERMAN MA, CALKINS CM, POMERANTZ BJ, MCINTYRE RC JR, HARKEN AH, MENG X: Neutralization of IL-18 attenuates lipopolysaccharide-induced myocardial dysfunction. Am J Physiol Heart Circ Physiol 283: 650-657, 2002.

SATIRAPOJ B, SIRITAWEESUK N, SUPASYNDH O: Urinary angiotensinogen as a potential biomarker of diabetic nephropathy. Clin Kidney J 7: 354-360, 2014.

SIEGMUND B: Interleukin-18 in intestinal inflammation: friend and foe? Immunity 32: 300-302, 2010.

SPARKS MA, CROWLEY SD, GURLEY SB, MIROTSOU M, COFFMAN TM: Classical renin-angiotensin system in kidney physiology. Compr Physiol 4: 1201-1228, 2014.

URUSHIHARA M, KOBORI H: Angiotensinogen expression is enhanced in the progression of glomerular disease. Int J Clin Med 2: 378-387, 2011.

URUSHIHARA M, NAGAI T, KINOSHITA Y, NISHIYAMA S, SUGA K, OZAKI N, JAMBA A, KONDO S, KOBORI H, KAGAMI S: Changes in urinary angiotensinogen post treatment in pediatric IgA nephropathy patients. Pediatr Nephrol 30: 975-982, 2015.

WOLDBAEK PR, SANDE JB, STROMME TA, LUNDE PK, DJUROVIC S, LYBERG T, CHRISTENSEN G, TØNNESSEN T: Daily administration of interleukin-18 causes myocardial dysfunction in healthy mice. Am J Physiol Heart Circ Physiol 289: 708-714, 2005.

WONG E, CHALLIS R, SHEERIN N, JOHNSON S, KAVANAGH D, GOODSHIP TH: Patient stratification and therapy in atypical haemolytic uraemic syndrome (aHUS). Immunobiology 221: 715-718, 2016. 
YAMAMOTO T, NAKAGAWA T, SUZUKI H, OHASHI N, FUKASAWA H, FUJIGAKI Y, KATO A, NAKAMURA Y, SUZUKI F, HISHIDA A: Urinary angiotensinogen as a marker of intrarenal angiotensin II activity associated with deterioration of renal function in patients with chronic kidney disease. $J$ Am Soc Nephrol 18: 1558-1565, 2007.

ZORRILLA EP, SANCHEZ-ALAVEZ M, SUGAMA S, BRENNAN M, FERNANDEZ R, BARTFAI T, CONTI B: Interleukin-18 controls energy homeostasis by suppressing appetite and feed efficiency. Proc Natl Acad Sci USA 104: 11097-11102, 2007.

ŻUROWSKA A: Hemolytic uremic syndrome in children and adolescents (in Polish). Forum Nefrologiczne 5: 283-288, 2012. 